\title{
Fjärrundervisning - en central del i skolans digitalisering
}

\author{
Jörgen From ${ }^{1}$ \\ Umeå universitet \\ Fanny Pettersion \\ Umeå universitet \\ Gerd Pettersson \\ Umeå universitet
}

\begin{abstract}
I denna artikel analyseras fjärrundervisning i relation till skolans digitalisering, med Nivåer av Lärande som teoretiskt ramverk. Detta görs med utgångspunkt i de försök till digitalisering som sedan 1980-talet pågått i svensk grund- och gymnasieskola, och den brist på pedagogiska objekt i termer av skolans undervisningsuppdrag som kännetecknar dessa försök. Ytterligare en del i föreliggande studie utgör en historisk beskrivning av fjärrundervisningens framväxt i svensk skola, där fjärrundervisning varit ett sätt att hantera skolans behov. Sedan redovisas ett empiriskt case om lärares erfarenheter från, och perspektiv på, egen fjärrundervisning i svensk skola. Detta tydliggör att lärarna använder digital teknik i ett målinriktat pedagogiskt syfte, vilket i detta sammanhang innebär att digital teknik är verktyg för att bedriva fjärrundervisning. Slutligen förs en diskussion kring vad som kännetecknar det pedagogiska objekt och den pedagogiska process som utvecklas och realiseras på olika nivåer i skolorganisationen i samspelet mellan fjärrundervisning och skolans digitalisering. Den slutsats som dras är att skolans digitalisering snarare är en fråga om pedagogik än om teknik.
\end{abstract}

\section{INLEDNING}

Skolans digitalisering har en till synes lång historia i Sverige. Första tecknen på digitalisering kom under 1960-talet med resonemang om datorns framtida roll i klassrummet. Digitaliseringen tog ordentlig fart på nationell nivå under 1980-talet, med tydliga krav och statligt finansierade digitaliseringsinitiativ med syftet att öka integrering och användning av digital teknik i klassrummet 
(se Jedeskog, 2005; Perselli, 2014; Perrotta \& Evans, 2013; Tallvid, 2015). Medan nationella satsningar har visat sig ge möjligheter att över tid bygga upp tekniska och digitala infrastrukturer, har inverkan på pedagogisk och organisatorisk utveckling skett i mer begränsad omfattning (Hylén, 2013; Jedeskog, 2005; Håkansson-Lindqvist, 2015). Förklaringar har relaterats till digitaliseringens brist på pedagogiska objekt, top-down styrda initiativ med bristande koppling till lärares praktik, samt brist på mål, visioner och support i skolorganisationen (Hylén, 2013; Håkansson-Lindqvist, 2015; Jedeskog, 2005, se även internationella exempel som Petko, Egger, Cantieni \& Wespi, 2015). Detta har dock inte dämpat den teknikoptimism som de senaste fyra årtiondena präglat såväl forskning som policy på området (Player-Koro, 2016). Ny teknik har hela tiden framhållits som lösningen på skolans problem inklusive de problem som skolan snarare tillskrivits än uppvisat (Player-Koro, 2016).

Inom ramen för skolans digitalisering finns dock exempel där skolans utvecklingsbehov drivit på integreringen av IKT med mer djupgående och långvariga förändringar $\mathrm{i}$ den pedagogiska och organisatoriska praktiken (Pettersson, 2018b). Fjärrundervisning utgör ett sådant exempel (From \& Pettersson, 2018; Pettersson, 2018a; Pettersson \& Olofsson, 2019). Kunskap om fjärrundervisningens utveckling i Sverige, samt hur pedagogiska och organisatoriska utvecklingsprocesser kan analyseras och förstås i relation till den pågående digitaliseringsprocessen i svensk skola är dock ej så utvecklad. Syftet med denna artikel är att analysera och förstå fjärrundervisning $\mathrm{i}$ relation till skolans digitalisering. För att uppnå detta syfte används aktivitetsteori och konceptet Nivåer av Lärande skapat av Bateson (1972) och utvecklat av Engeström (1987) som teoretiskt ramverk.

\section{Nivåer av Lärande}

Det finns ett flertal studier som pekar på avsaknad av teoretiska och konceptuella ramverk för att analysera och förstå aspekter av fjärrundervisning i grund- och gymnasieskola (Barbour, 2018). Detta innebär enligt Barbour (2019) att fältet länge karaktäriserats av lärares egna utsagor och best practice utan teoretiska och konceptuella raster som förklaringsmodeller. För att undersöka och förstå hur utveckling och förändring sker när förutsättningar för en praktik förändras, $\mathrm{i}$ detta fall undervisning i svensk skola, används kulturhistorisk aktivitetsteori och konceptet Nivåer av Lärande (översatt från Levels of learning, framtaget av Bateson, 1972; utvecklat av Engeström, 1987). Karaktäristiskt för aktivitetsteori är fokus på utveckling och transformation. Studier visar samtidigt att transformation $i$ utbildningssektorn ofta utgörs av långsamtgående processer influerade av normer och traditioner om hur skola och undervisning ska vara och fungera (Pettersson, 2015; Hauge, 2014). Därför används i denna studie Nivåer av Lärande som grund för analytiska 
kategorier (jf. Bateson, 1972; Engeström, 1987; de Lange, 2010) för att kunna analysera och diskutera mindre, men framtida potentiella, steg av transformation avseende digitalisering i svenska skola.

Konceptet Nivåer av Lärande, som också utgör en central del i det aktivitetsteoretiska transformationsbegreppet, har beskrivits av Bateson (1972) och senare Engeström (1987) som tre steg av utveckling: Lärande I, Lärande II och Lärande III. Det första steget, Lärande I (LI), karaktäriseras av extremt långsam utveckling $\mathrm{i}$ form av förbättring av verktyg. Lärande II är en mer komplex form av utveckling, och har av Engeström (1987) delats in i två former: Lärande IIa (LIIa) som en reproduktiv form av utveckling och Lärande IIb (LIIb) som en mer produktiv form. LIIa, med hög grad av reproduktion, innebär exv. utveckling av nya digitala verktyg men som används tillsammans med gamla undervisningsmetoder. Kombinationen av gamla och nya verktyg och traditioner kan, som framgår av Engeström (1987) och de Lange (2010), orsaka störningar i den reguljära verksamheten, vilket i sin tur kräver experimenterande med nya undervisningsmetoder. Att testa och experimentera med nya metoder och strategier genom att reflektera och ifrågasätta det gamla, kännetecknar LIIb. Även om LIIb resulterar i mer omfattande förändringar, såsom exv. ny undervisningspraxis, är spridningen begränsad till individnivå ( $\mathrm{t}$ ex lärare och lärarlag). När förändringen sprids och får förankring på kollektiv nivå med kvalitativa förändringar i praktik, struktur, mål och organisation sker en transformation av hela aktivitetssystemet som en del av LIII (Engeström, 1987) vilket kan orsaka påfrestningar och utmaningar för de inblandade.

Tabell 1. Exempel på lärandenivåer i digitaliserade utbildningskontexter (inspirerad av Bateson, 1972; Engeström, 1987)

\begin{tabular}{|l|l|}
\hline Lärandenivåer & Utvecklingssteg \\
\hline LI & $\begin{array}{l}\text { Digitalisering som småskalig utveckling och användning av } \\
\text { digitala verktyg för att stötta befintlig praktik }\end{array}$ \\
\hline LIIa & $\begin{array}{l}\text { Digitalisering som implementering av digitala verktyg för att } \\
\text { stötta men inte förändra befintlig praktik }\end{array}$ \\
\hline LIIb & $\begin{array}{l}\text { Digitalisering som implementering av digitala verktyg samt } \\
\text { utveckling av nya undervisnings- och lärandepraktiker med } \\
\text { spridning till hela lärarlag }\end{array}$ \\
\hline LIII & $\begin{array}{l}\text { Digitalisering som utveckling av nya sätt att undervisa, arbeta, } \\
\text { kommunicera och organisera hela skolorganisationen }\end{array}$ \\
\hline
\end{tabular}

I följande avsnitt ges, med stöd av lärandenivåerna, en beskrivning av de försök till digitalisering som sedan 1980-talet pågått i svensk grund- och gymnasieskola, följt av en historisk beskrivning av fjärrundervisningens framväxt i svensk skola. I artikeln presenteras därefter ett empiriskt case som fokuserar lärares erfarenheter från, och perspektiv på, sin egen utveckling av 
fjärrundervisning i svensk skola. Analysen fokuserar hur lärare hanterar digital och pedagogisk förändring och hur det kan kopplas till olika lärandenivåer. I den avslutande delen av artikeln förs en diskussion kring vad som kännetecknar det pedagogiska objekt och den pedagogiska process som utvecklas och realiseras på olika nivåer i skolorganisationen i samspelet mellan fjärrundervisning och skolans digitalisering. Diskussionen avslutas med en del kritiska reflektioner och förslag kring fortsatt forskning på området.

\section{SKOLANS DIGITALISERING}

Digitalisering i svenska grund- och gymnasieskolor är en pågående process, med spår tillbaka 1960-talet (Karlsohn, 2009). Under 1960-talets slut visade svenska beslutsfattare inom skolområdet stort intresse för hur teknik och datorer kunde påverka skolans undervisning. Under 1970-talet kom ett antal mindre satsningar såsom Datorn I Skolan (DIS) med nyckelorden om, med och av datorer. Arbetet med skolans digitalisering tog ordentlig fart under 1980talet, med tydliga krav på nationell nivå att öka integrering och användning av digital teknik i klassrummet (se Jedeskog, 2005; Perselli, 2014; Perrotta \& Evans, 2013; Tallvid, 2015). Med detta följde en rad nationella försök att driva skolans digitalisering, med ambition att skapa bättre förutsättningar för lärande och utveckling, samtliga baserade i en optimistisk syn på ny teknik som lösning på alla skolans problem (Player-Koro, 2016). Dessa försök har beskrivits av Jedeskog (2005; se även Perselli, 2014; Tallvid, 2015) som fyra vågor som dragit in över svensk skola med målet att öka skolledares, lärares och elevers IKT-användning (Håkansson-Lindqvist, 2015).

Under början av1980-talet utfärdade regeringen (Skolöverstyrelsen, 1980) den första läroplanen (Lgr80) som lade vikt vid 'datalära' och datorns roll i undervisningen. Under samma tidsperiod introducerades, som ett första steg mot ökad teknik i skolan, COMPIS (COMPuter In School) med upphandling av datorer som skulle passa undervisning. Under 1980-talets slut kom även det treåriga projektet Datorn Och Skolan (DOS) (Söderlund, 2000), med målet att öka och stärka integreringen av digital teknik i undervisningen. DOS-projektet beskrevs som tredelat med försöksverksamhet ute i skolor, samt regionalt- och centralt utvecklingsarbete. Trots politiska mål och finansiella satsningar för att köpa in datorer, uppnåddes inte den förväntade utvecklingen $\mathrm{i}$ undervisningen. Förändringarna karaktäriserades snarare av mindre tekniska implementeringar som går att likna med aspekter av LI.

Under slutet av 1980-talet och under början av 1990-talet genomfördes två reformer med stor inverkan på svensk skola. Ansvaret för skolor skiftade från stat till kommun, och 1992 inrättades en ny myndighet - Skolverket - som bland annat fick ett uttalat uppdrag att producera och tillhandahålla digitala verktyg och tjänster i skolan (Håkansson-Lindqvist, 2015). Inom ramen för uppdraget tillsatte Skolverket ett antal projekt för att kartlägga tillgången till 
datorer i svenska grundskolor. Resultaten visade på bristande datorkunskaper hos lärare, och begränsade resurser för att köpa in hård- och mjukvara (Hylén, 2013). 1994 inrättades Stiftelsen för kunskaps- och kompetensutveckling (KK-stiftelsen) som ett statligt forskningsstödjande organ för att stärka Sveriges konkurrenskraft. Samma år gav Regeringen KK-stiftelsen i uppdrag att stötta och sprida IT-användningen inom svenska skolor. Med uppdraget följde starka finansiella resurser till kommuner, och till forskning om IT i skolan. Totalt omfattade uppdraget 27 större skolutvecklingsprojekt med totalt 51 inblandade kommuner som tillsammans skulle leda vägen för ökad digitalisering i skolan (Jedeskog, 2005). Den nya tekniken sågs alltjämt som lösningen på skolans problem, men trots omfattande resurser och rikstäckande spridning uppfyllde satsningen inte heller denna gång de förväntade målen om digitalisering av den svenska skolan. Satsningarna på skolans digitalisering låg vid denna tidpunkt på vad som kan förstås som aspekter av LIIa, det vill säga nya digitala verktyg men samma praktik som förr, men där förväntningarna från policynivå om större förändring och transformation i skolan närmade sig vad som kan liknas med LIII.

Under 1990-talet kom även SOU-texten Vingar åt människans förmåga (SOU 1994:118) med fokus på IT-användningens betydelse för skolområdet, och sedan regeringens skrivelse Lärandets verktyg (1997/98:176) med infrastrukturfrågor och lärarfortbildning i fokus. Under 1990-talet genomfördes även satsningar som ITiS (IT i Skolan, en av de historiskt största lärarsatsningarna i Sverige). Enligt Karlsson (2004) nådde ITiS omkring 75000 lärare, i nästan alla kommuner, vilket då utgjorde cirka $60 \%$ av alla lärare i Sverige. Satsningen fokuserade dels på infrastruktur med en dator till varje lärare, och dels på en ökad kompetensutveckling med lärare som förändringsagenter. Som forskning visade fick satsningen positivt bemötande. Lärare fick möjlighet att diskutera samarbeta med kollegor både inom och mellan skolor och den upplevda IT-kompetensen ökade, men kraven på förändrade arbetspraktiker var påtagliga (Chaib, Chaib \& Ludvigsson, 2004; Jedeskog, 2005; Karlsson, 2004). Även vid denna tid återspeglar försöken till att digitalisera den svenska skolan av satsningar på ny teknik (LIIa), men förväntningarna på skolans transformering kan sägas likna LIII.

Praktisk IT- och Mediekompetens (PIM) lanserades 2006 av Myndigheten för skolutveckling, på uppdrag av regeringen, som en fortutbildningsinsats för att tillhandahålla IKT-verktyg och öka IT-kompetensen hos lärare i svenska skolor. PIM genomfördes, fram till det avvecklades 2014, av 150000 lärare och skolledare (Skolverket, 2016). Programmet, som gavs individuellt eller i grupp, var gratis för skolan, och innehöll fem olika nivåer av IKT-kompetens. Under samma tidsperiod, med start under 2010-talet kom implementeringsprojekt som 1:1 (en dator, en elev) med syftet att fortsatt stimulera skolans digitalisering (Grönlund, 2014; Håkansson-Lindqvist, 
2015). Detta möjliggjordes av att många svenska skolor vid denna tid var utrustade med trådlöst internet (Hylén, 2013).

De höga förväntningarna på policynivå, och de därtill hörande nationella satsningarna på teknik i klassrummet gav dock inte önskat utfall. Enligt Skolinspektionens (2012) rapport hade exv. tillgången till digitala teknologier i skolan (karaktäriserat av LIIa) ökat medan förändringar i undervisningspraktiken (LIIb) hade realiserats i betydligt mindre omfattning. Att lärarnas behov och erfarenheter förbisågs i top-down implementeringarna (Hylén, 2013; Jedeskog, 2005; Håkansson-Lindqvist, 2015), samt en otydlighet över huruvida skolans digitalisering skulle bidra till ett ökat lärande om datorn eller lärande med datorn som stöd (Söderlund, 2000; HåkanssonLindqvist, 2015), är några av de förklaringar som identifierades. Detta framkom även av Skolverket som på uppdrag av regeringen utvärderat ITanvändningen och IKT-kompetens i förskola, skola och vuxenutbildning. I Skolverkets rapporter $(2009,2013$, 2016) lyftes exv. behovet av strategiskt ledarskap och professionell utveckling inom alla nivåer i skolan samt behovet av att integrera IKT i undervisningen på ett mer medvetet och strukturerat sätt (strategiska satsningar som skulle kunna förstås som mål om LIII). Dessa aspekter återspeglas även i de senaste förändringarna i den svenska läroplanen (Skolverket, 2019), i den nationella strategin för skolväsendet (Utbildningsdepartementet, 2017) och i den nationella handlingsplanen för skolans digitalisering (Sveriges Kommuner och Landsting, 2019).

Liknade utvecklingsprocesser, vilka skulle kunna förstås i termer av LIIa, har även beskrivits i internationell forskning (Hauge, 2014; Haelermans, 2017; Player-Koro, 2016; Bock och Probst, 2018). Haelermans (2017) menar exv. i sin studie att "Simply having access to ICT in education will not necessarily lead to an effective use of ICT in education." (p.101). Som Player-Koro (2016) menar bidrar digitaliseringssatsningar i många fall till att reproducera, snarare än transformera, sedvanlig undervisningstradition (jfr även Agélii Genlott, Grönlund \& Viberg, 2019; Player-Koro, 2013). Detta innebär enligt Bock och Probst (2018), att digital teknik används för att stötta men inte förändra undervisningen. Enligt Player-Koro (2016) och Williamson (2019) kan det tekniska fokuset förstås ha sin grund i ett neoliberalt förhållningssätt där skolan blir en del av en marknad med stora finansiella intressen i att utrusta skolan med ny teknik, oavsett skolans faktiska behov av ny teknik, hur den kan användas och i vilka pedagogiska sammanhang. Hague (2014) menar närmare att de långsamtgående pedagogiska utvecklingsprocesser beror på skolans starka normer och traditioner som inte så lätt låter sig utmanas av ny digital teknik. Som Vanderlinde, Aesert och van Braak (2015) visar ställer mer omfattande IKT-implementeringar högre krav på klassrumskultur, rollfördelning och anpassning till nya förutsättningar.

Agélii Genlott och Grönlund (2016) menar att IKT-användning som inte integreras med ett tydligt pedagogiskt mål och med en pedagogisk metod kan 
ge sämre resultat i skolan än om det inte används alls. Liknande studier visar hur IKT-användningen blir som mest effektiv när den grundas på, och kopplas till, pedagogiska mål och strategier (Jahnke \& Kumar, 2014; Jahnke et al. 2017) och med tydlig support från övergripande strukturer (Agélii Genlott, Grönlund \& Viberg, 2019: Ottestad, 2013; Petko et al., 2015; Pettersson, 2018b). Digital kompetens, lärares designval och organisatoriska stödstrukturer framstår därmed som frågor av relevans utöver de om tillgång till ny teknik i klassrummet (se även Jahnke \& Kumar, 2014; Jahnke, Bergström, Mårell-Olsson, Häll \& Kumar, 2017; Olofsson \& Lindberg, 2014; Ottestad, 2013; Hague, 2014; Warschauer, Zheng, Niiya, Cotten \& Farkas, 2014). Andra studier pekar även på digitaliseringens multidimensionella karaktär med de komplexa system som påverkar digitalisering på olika nivåer. Vanderlinde et al. (2015) menar exv. att förutsättningar på individuell lärarnivå (t ex digital kompetens, professionell utveckling) och organisationsnivå ( $\mathrm{ex}$ skolans visioner, digitalt skolledarskap) på olika sätt kan antingen hindrar eller stödjer IKT-användningen.

Även om digitalisering såväl nationellt som internationellt tenderar att resultera $\mathrm{i}$ teknisk utveckling relaterat till lägre Nivåer av Lärande (LI, LIIa) finns strömningar där digitalisering utgjort en pedagogisk fråga, med bas i skolans faktiska behov (se t ex Pettersson, 2018b). Som ett sådant exempel ges i nästa avsnitt en beskrivning av fjärrundervisningens utveckling i Sverige. Därefter presenteras studiens empiriska case.

\section{FJÄRRUNDERVISNING I GRUND- OCH GYMNASIESKOLA}

Parallellt med digitaliseringens framväxt finns exempel på undervisningspraktiker som förutsätter tillgång till digital teknologi, men är sprungna ur skolans behov, exv. av att ge elever och lärare likvärdiga förutsättningar oavsett skolans geografiska placering (Pettersson, 2009). Fjärrundervisning är ett sådant exempel, där en ny undervisningsform kräver omfattande digitalisering men också ett pedagogiskt och organisatoriskt utvecklingsarbete (From \& Pettersson, 2018; Pettersson, 2018a; Pettersson \& Olofsson, 2019), inte minst utveckling av nya arbetssätt och metoder för att kunna planera, genomföra och utvärdera undervisningsformen (Häll, Hällgren \& Söderström 2007; Millet, 2012; Xiong, Ge, Wang \& Wang, 2016).

Som tidigare nämnts är en av skolans största utmaningar att leva upp till alla elevers rätt till en likvärdig utbildning (Jobér, 2015), som i förlängningen ska skapa sociala och ekonomiska förutsättningar för såväl individ som samhälle (Lundahl, 2016). Likvärdighetsaspekten har under åren inte minst accentueras i små och medelstora kommuner som, i jämförelse med mer attraktiva storstadsregioner, ofta haft betydande svårigheter när det gäller att rekrytera behöriga rektorer och lärare (jfr Pettersson, 2017). Dessa svårigheter har i sin tur inskränkt på elevers rätt till undervisning av behöriga lärare, 
kanske främst i glesbygdsskolor och i specifika ämnen som minoritetsspråk eller elever i behov av extra stöd genom specialpedagogisk verksamhet (Pettersson, 2017). Denna problematik har varit påtaglig under lång tid, och lika länge har fjärrundervisning setts som en möjlighet att hantera lärarbrist och långa avstånd mellan skolor (jfr Häll, Hällgren \& Söderström, 2007; From \& Pettersson, 2018; Pettersson, 2017; Pettersson \& Olofsson, 2019).

Fram till 1970-talet tillhandahölls utbildning för elever i grundskoleåldern genom att skolor fanns där eleverna och deras familjer var bosatta, såväl i städer som i byar (Dahllöf, 1973), vilket innebar att eleven undervisades i den skola som låg närmast hemmet. Som en effekt av den tilltagande urbaniseringen, fanns dock insikten om att distansen mellan elevernas hem och skolan i många mindre kommuner skulle komma att öka (Dahllöf, 1973). Som senare framgick av Ubas studie (2015), lades 490 svenska skolor ner under perioden 1991-2010. För många elever ersatte långa och tidskrävande skolbussresor tid för läxläsning, lek med kamrater och andra fritidsaktiviteter (Andræ Thelin \& Solstad, 2005). För många skolor blev frågan om tillgång till behöriga lärare därmed alltmer komplex.

Under 2011 infördes även krav om lärarlegitimation och nya behörighetsregler (2011:326), vilket $\mathrm{i}$ sin tur förstärkte svårigheten att rekrytera behöriga lärare. Ett flertal av Sveriges kommuner fick därmed ordentliga problem med att leva upp till de juridiska krav som ställdes på utbildning och ett alternativ för att hantera problematiken var fjärrundervisning, som började diskuteras, inte minst ur ett likvärdighetsperspektiv, inom och mellan skolhuvudmän (se t ex Pettersson, 2009; Pettersson \& Olofsson, 2019; Häll, Hällgren \& Söderström 2007). Under 2000-talet prövades och utvärderades också fjärrundervisningsformatet i begränsad omfattning (se t ex Hegerholm, 2007; Häll, Hällgren \& Söderström 2007). Som framkom i utvärderingarna ansågs erfarenheterna av fjärrundervisningsformen viktig eftersom den inte bara förväntades bidra med likvärdig utbildning och behöriga lärare, utan även ett ökat utbildningsutbud.

Denna utveckling noterades även från myndighetshåll, och som ett resultat blev fjärrundervisning från 2015-07-01 tillåten men med viss begränsning vad gäller ämnen och genomförande (Skollagen, 2010:800). Enligt Skollagen (2010:800) skulle fjärrundervisningen bedrivas som en interaktiv undervisningsform med stöd av informations- och kommunikationsteknik (IKT). Enligt den nya lagen tilläts elever och lärare vara åtskilda i rum men inte $\mathrm{i}$ tid, så länge en handledare var närvarande i den lokal där eleverna befinner sig. Tillåtna skolämnen bestämdes till moderna språk, modersmål, samiska i sameskolan och teckenspråk, samt för att ge elever studiehandledning på modersmål och integrerad samisk undervisning (Skollagen, 2010:800).

I realiteten bedrivs dock fjärrundervisning $i$ en vidare omfattning än så, då fjärrundervisning för många skolor runt om i Sverige ses som ett sätt att 
hantera faktiska behov (se t ex Öjefors-Stark, 2019, Stenman \& Pettersson, 2020). Det kan till exempel handla om att tillämpa fjärrundervisning i andra ämnen än de som tillåts, inte tillåten användning av entreprenad, det kan även handla om elever som deltar i fjärrundervisning hemifrån eller en distansutbildning, som innebär kommunikation på annat sätt än i realtid (Skolverket, 2018). Digitaliseringen möjliggör för dessa skolor att utveckla fjärrundervisning som en ny undervisningspraktik för att hantera lokala och regionala behov, det vill säga en utveckling som rör sig på LIIb och kanske även LIII. Tilläggas kan att i februari 2020 kom en lagrådsremiss med förslag om utökade juridiska möjligheter att använda fjärr- och distansundervisning $\mathrm{i}$ det svenska skolsystemet, enligt förslaget ska förändringarna i Skollagen gälla från och med 200801 (Regeringen, 2020).

\section{FJÄRRUNDERVISNING - ETTT EMPIRISKT CASE}

Runt om i Sverige finns exempel där skolor och skolhuvudmän på olika vis arbetat för att utveckla former för fjärrundervisning och där digitala teknologier, sprungna ur skolans digitalisering, utgjort förutsättningar för denna utveckling. För att synliggöra vad som kan ske på olika nivåer i skolorganisationen, när fjärrundervisning med stöd av skolans digitalisering introduceras och utvecklas, används i denna artikel ett empiriskt case med fokus på lärares erfarenheter. Caset baseras på ett forsknings- och utvecklingsprojekt (finansierat av Vinnova och projektägare var Ifous, delar av empirin är presenterad i projektets slutrapport) av fjärrundervisning $i$ svensk skola åren 2016-2017. De 35 lärare som medverkade hade via respektive rektor anmälts till FoU-studien om fjärrundervisning. I samband med starten av FoU-projektet informerades deltagarna om att varierade data skulle samlas in och att allt deltagande i den forskningsbaserade delen var frivilligt. Detta innebär att etiska krav och principer gällande information, samtycke, konfidentialitet och nyttjande för humaniora och samhällsvetenskap (Vetenskapsrådet, 2017) har följts. Information om frivilligt deltagande och möjligheten att avsluta deltagandet i studierna upprepades också vid respektive datainsamling.

\section{Metod och genomförande}

Designen för datainsamlingen bestod av två mätningar via webbenkäter samt processdata genom pedagogernas loggböcker under läsårets gång. Data tar avstamp i kvalitativa och kvantitativa metoder och styrkan som tillskrivs varierade metodkombinationer är att under en relativt kort projektperiod, erhålls tillförlitlig och variationsrik kunskap om fjärrundervisning samt att denna form av metodtriangulering stärker tillförlitligheten av resultaten (Creswell, 2003). Ytterligare ett skäl för metodval var att studien omfattade 
ett geografiskt vidsträckt område och i relation till långa avstånd hade det inte varit möjligt att besöka och intervjua samtliga deltagare.

Den första webbenkäten genomfördes vid projektets start i oktober 2016, och den andra i slutet av projektåret i oktober 2017. Enkäterna syftade till att ge data om lärarnas inställning till IKT och undervisning i allmänhet, och till fjärrundervisning i synnerhet. De 29 frågor i enkäterna bestod av fasta svarsalternativ och öppna frågor, som möjliggjorde mer fördjupade fritextsvar. Frågorna i webbenkäten var tematiserade och enkäten omfattade, förutom bakgrundsfrågor om respondenterna, följande temaområden; förväntningar på fjärrundervisning, förväntningar på det egna lärandet, framtiden, om digitala verktyg. Den andra enkätundersökningen bestod av samma frågor men med fokus på erfarenheter snarare än förväntningar.

Förutom att besvara webbenkäterna blev lärarna ombedda att föra loggbok (jfr Moon 2006) en gång varannan vecka från mitten av oktober 2016 till maj 2017. Loggbokenskrivandet syftade till att dokumentera utvecklingen av den egna undervisningsprocessen, både hur den planerades och hur den genomfördes. För att vägleda lärarna i skrivprocessen formulerades följande övergripande rubriker: 1) Så här planerar jag närundervisningen och såhär planerar jag fjärrundervisningen, 2) Så här genomför jag oftast lektionerna med fjärrundervisningen, 3) Egna tankar, funderingar och reflektioner (ex planering, genomförande eller efterarbeten eller annat). För att erhålla ytterligare detaljer uppmanades lärarna även att exemplifiera det egna ämnet genom att bifoga lektionsplaneringar.

\section{Urval, deltagare och bortfall}

Samtliga lärare i FoU-studien erbjöds att fylla i de båda webbenkäterna och att föra loggböcker om undervisningsprocessen när fjärrundervisning tillämpas och när traditionell undervisning genomförs. Webbenkäten besvarades av totalt 35 deltagare varav 14 respondenter besvarade enkäterna i sin helhet, samt förde loggbok.

Respondenterna representerade grund- och gymnasieskolor som på eget initiativ beslutat om att bedriva fjärrundervisning i olika skolämnen. Utmärkande för respondentgruppen var att det handlade om erfarna lärare som oftast arbetat mer än tio år i skolan. Det empiriska underlaget i föreliggande studie är i huvudsak hämtat från webbenkäternas fritextsvar och loggböckernas texter.

Att 21 lärare valde att ej fullt ut besvara enkäter och skriva loggböcker kan vara ett problem för studiens tillförlitlighet. Bortfallet kan delvis bero på att fjärrundervisning var en relativt ny företeelse för de allra flesta lärarna och av det skälet kan lärarna ha valt att använda tiden till planering och genomförande av fjärrundervisning samt att följa elevernas kunskapsutveckling och i lägre grad till att besvara enkäter och dokumentera i loggböcker. De faktum att enbart 14 respondenter besvarade enkäterna och 
loggboken kan således bero på en upplevd eller en verklig tidsbrist. En annan anledning kan vara stor arbetsbörda eftersom fjärrundervisning initialt tar längre tid att planera jämfört med traditionell undervisning.

\section{Bearbetning av data}

Efter att all data samlats in gjordes genomgångar och flera genomläsningar av allt material. För att analysera materialet gjordes en innehållsanalys med syfte att utkristallisera centrala teman i data utifrån de olika lärandenivåerna (Graneheim \& Lundman, 2004). Analysprocessen fokuserade på att sammanställa, systematisera och gruppera respondenternas utsagor i syfte att upptäcka mönster som i sin tur kunde utgöra innehåll i de potentiella teman. Analysprocessen gav underlag för tre provisoriska teman: (1) Lärande IIa, (2) Lärande IIb samt (3) Efterfrågan på Lärande III.

För att skapa en helhet av studiens resultat och de tre analytiska teman gjordes även en analys av den tidsmässiga dimensionen i materialet för att se om det fanns en möjlig kronologisk ordning i innehåll och mellan teman. Analysen resulterade slutligen i följande tre teman (i kronologisk ordning):

- Utgångspunkt i teknik (LIIa)

- Från teknik till pedagogisk utveckling (LIIb)

- Organisation och strategiskt ledarskap (efterfrågan på LIII)

Den kronologiska ordningen, vilken också kunde påvisa en utvecklingsprocess, jämfördes slutligen mot materialet $\mathrm{i}$ sin helhet genom en ytterligare genomläsningar av loggböcker och enkätsvar. Den sammantagna analysen resulterade i ett material som kunde beskriva den pedagogiska och organisatoriska process som utvecklas och realiseras på olika nivåer i skolorganisationen, i skärningspunkten mellan fjärrundervisning och skolans digitalisering.

\section{RESULTAT}

I föreliggande avsnitt presenteras resultatet från det empiriska caset. Detta görs med utgångspunkt i tre övergripande teman enligt ovan. Respondenterna kommer att benämnas som R1-R14.

\section{Utgångspunkt i teknik}

De ingående skolornas motiv för att utveckla och implementera fjärrundervisning är och har varit varierande. Några exempel är bristen på behöriga lärare, ge lärare tillgång till fler elever, lärares arbetstid fokuserad till undervisning snarare än till resor mellan skolor, ge elever tillgång till fler behöriga lärare, bredda tillgången av ämnen för elever samt samverkan inom 
och mellan kommuner, för att därmed skapa möjligheter att leva upp till alla elevers rätt till en likvärdig utbildning. Mer konkret tycks det handla om att skolaktörerna erhåller fler verktyg och metoder med avseende på att uppnå och tillgodose skollagen (2010:800). Trots beskrivna motiv har dock många skolor, historiskt sett, inte haft tekniska förutsättningar för att bedriva fjärrundervisning, vilket sammanfattas i följande citat: De tekniska förutsättningarna på den tiden [under 90-talet] satte delvis stopp för planerna med rena fjärlektioner (R5).

Som framgick av resultaten från den första enkäten kände sig lärarna vid läsårets start ganska positivt inställda till utveckling och implementering av fjärrundervisning. Fjärrundervisningsformatet beskrevs som en möjlighet att utveckla, organisera och genomföra nya undervisningsformer som en del av den egna professionsutvecklingen. Även förväntningarna för elevernas del var, enligt såväl lärarenkäter som loggböcker, höga avseende på exv. social interaktion, elevers utveckling och för att kompensera och överbrygga frånvaro för sjukdom och för så kallade "hemmasittare".

Gemensamt för lärarna var också att de vid terminsstart såg fungerande teknik som den enskilt viktigaste faktorn för att lyckas med fjärrundervisning, likväl som att man såg teknikstrul som det enskilt största hindret mot att lyckas. Flera tidiga noteringar i loggböckerna rör fokus på ljudteknik, dålig ljudkvalitet försvårade eller i sämsta fall omöjliggjorde lärarens och elevernas diskussioner, uppkopplingar som inte fungerat vilket försinkat lektionsstarter var andra tekniska problem som framkom i loggböckerna. Centralt i lärarnas reflektioner från tidig höst är frågor om vilken utrustning eller mjukvara som fungerar bäst, eller tvivel på sin egen kunskap om IKT. Bekantar mig med Google hangout genom att titta på Youtube filmer, samt testkör programmet (R13). Teknikstrul är en faktor som man nog måste räkna med. Vi har provat lite olika lösningar men alla har sina brister även om vissa fungerar bättre och vissa sämre. Det viktiga är som jag ser det att alltid ha andra möjliga alternativ för kommunikation tillgängliga (R4). Ettproblem har varit att det känts obekvämt för eleverna att prata rätt ut med en "skärm" (R12). Ljudet hackade lite grann (R1).

En annan aspekt som framkommer i loggböckerna under tidig hösttermin 2016 är fokus på tidsåtgången för planeringsarbetet. Från loggböcker och lektionsplaneringar är det exv. tydligt att lärarna lade mer tid på såväl för- som efterarbete vid fjärrundervisning, i jämförelse med sin vardagliga närundervisning. En del av den ökade tidsåtgången anges vara att planeringsoch efterarbete $\mathrm{i}$ högre grad görs skriftligt, en annan del kopplas till lärarnas egna begränsade erfarenheter av fjärrundervisning. I detta avseende relateras till krånglande teknik, vilket innebar att lärarna kände sig tvungna att utarbeta alternativa lösningar i sina lektionsplaneringar för att kunna hantera just teknikstrul. Sammantaget är det relativt problematiserande reflektioner i underlaget, exv.: Ibland känns det som att detta aldrig kommer att fungera (R4) eller Funderar också på om elever och lärare har lättare att vara mer flexibla och spontana $i$ ett 
fysiskt klassrum? Eller om det enbart är en vana? (R6). Det förekommer tvivel på om fjärrundervisning passar eleverna, då vissa förefaller ovana och osäkra.

\section{Från teknik till pedagogisk utveckling}

Under senare delen av hösten 2016 tycks det dock ske en märkbar förändring, teknik och tidsåtgång tonar ut alltmer ur det empiriska underlaget och istället förskjuts intresset alltmer till pedagogiska reflektioner. Det handlar dels om social interaktion, hur kunna se och bekräfta alla eller hur fördela ordet i diskussionsövningar, men framför allt om att utveckla en metodvariation inom ämnet och fjärrundervisningsformen. Exv. att kunna variera mellan bild- och filmvisning, genomgång av faktatexter, skrivövningar och att träna elever i att skriftligt och muntligt redovisa och uttrycka sina åsikter. Tre lärare uttrycker detta som: Jag utvecklar fler sätt att kommunicera med eleverna via dator och kanske testa fler arbetssätt som inte centrerar så mycket kring att jag ska föreläsa kring varje nytt område (R8), respektive Bättre planering, roligare lärmiljö. Alla elever får bra undervisning (R5). Jag ville gärna vara påläst och kunna visa powerpoint eller tankekearta beroende pà vilket ämne det är (R3).

Parallellt med detta börjar reflektioner kring behov av ett pedagogiskt kollegialt utbyte med andra lärare som fjärrundervisar att dyka upp i materialet. Med andra ord riktas lärarnas intresse alltmer mot designfrågor kring fjärrundervisning, vilket innebär olika sätt att planera och genomföra fjärrundervisningen. Detta kan förstås som ett behov av att lärarna får de pedagogiska förutsättningar de eftersträvar för att kunna genomföra fjärrundervisning av god kvalitet (som de själva bedömer det). Tydligare struktur, bilder, kopplingar till vardagen, elevens egna erfarenheter (R14). Jag hade gett eleverna i läxa att se genomgängarna innan lektionen (R8). Planerade horisontell inlärning, elev lär av elev, dvs slags kamratinlärning. Eleverna gjorde en Power Point presentation med svåra ord, bilder etc. som gjorde att eleverna lättare kunde ta anteckningar under presentationerna och de förstod därigenom bättre varandras presentationer på franska (R11).

Under vårterminen 2017 ger lärarna uttryck för att vara alltmer nöjda med den egna fjärrundervisning och utsagorna vittnar om att lärarna börjar se en potential för pedagogisk utveckling: Ett roligt sätt att arbeta och som ger stora möjligheter för att utveckla undervisningsmetoder, elevkontakter, mtrl. (R9). Sammantaget förefaller utvecklingsrörelsen ge utfall även till eleverna, som enligt lärarnas utsagor har gått till alltmer nöjda elever. Även avseende tid och tidsåtgång har perspektivet skiftat, fjärrundervisning beskrivs som något som sparar tid och möjliggör en mer effektiv tidsanvändning, exv. för de lärare som slipper resor till eleverna. Det är dock främst två andra aspekter som betonas, det ena är att de digitala material man utvecklat går att återanvända på ett smidigt sätt och det andra är att materialen och tekniken fungerar så pass bra att man börjat använda dem i sin dagliga undervisning: Främst genom integreringen av digitala lärresurser och digitala verk.tyg i undervisningen (R2). 
Efter ett läsår med fjärrundervisning uppger lärarna även att de har utvecklat en digital samverkan med sina elever som fungerar, och de ser fjärrundervisning som något som utvecklar alla elever. Detta kan tyckas motsägelsefullt då det enbart är vissa elever som berörs av fjärrundervisning, men många tycks vara övertygade om att satsningen på fjärrundervisning har gett Bättre IKT-kunskaper för mig som lärare (R1), vilket kommer alla elever tillgodo.

Sammantaget uppges satsningen på fjärrundervisning som utvecklande för den egna pedagogiska planeringen och genomförandet av undervisningen, vilket skulle kunna förstås som att lärarna ser fjärrundervisning som en del av sin professionella utveckling. Framför allt betonas att fjärrundervisning inneburit att man organiserar sin undervisning på ett annat sätt än tidigare, att nya former av undervisning utvecklats, att samarbetet mellan kollegor på skolan, men också med andra utanför den egna skolan, blivit bättre.

\section{Organisation och strategiskt ledarskap}

Inom det tredje, och i kronologisk ordning avslutande, temat pekar lärarnas reflektioner ut ett ökat behov av dels ett kollegialt samarbete, dels ett strategiskt ledarskap för att ge förutsättningar till fortsatt utveckling. Detta relateras till flera aspekter, där en är den struktur och den organisation som behövs för att bedriva fjärrundervisning av god kvalitet. Bara det faktum att fjärrundervisning inbegriper en fjärrlärare, en handledare och kanske en ITpedagog samt schemaläggning vid olika skolenheter understryker behovet av samordning och struktur, menar lärarna. En annan aspekt som betonas är att fjärrundervisning har en potential att leda till generell pedagogisk utveckling, men det förutsätter samordning kring infrastruktur och lärresurser. En tredje aspekt, men sammanflätad med de första två, rör det behov av ökad kollegialitet och samordning som lärarna ser: Lyckas inte om enskilda lärare ska driva själva, behöver stöd från rektor och förutsättningar organisatoriskt (R7).

Som framkommer i såväl loggböcker som enkäter tycks lärarnas erfarenhet av fjärrundervisning ytterligare ha förskjutits $i$ en positiv riktning. De flesta lärarna ser fjärrundervisning som en vital del $\mathrm{i}$ den egna professionella utvecklingen, samt att fjärrundervisning leder till utveckling i planering och genomförande av den egna undervisningen. Ett av många exempel är följande: eleverna fär välja ett av de förvalda ämnesområdena som finns på ett delat google docs på lärplattformen. Uppgiften är att i par göra en kort film om varsitt fördjupningsområde. Filmerna ska sedan läggas upp på lärplattformen (R10). Överlag ser man att fjärrundervisning innebär nya former av undervisning och för att lyckas med detta anger ingen 'Fungerande teknik' som en viktig faktor, i stället betonas förhållningssätt, samarbete och ledarskap. I den utveckling som skett under läsåret så kan två huvuddrag urskiljas, lärarna har gått: 
1) Från att se fjärrundervisning som ett alternativ till reguljär undervisning, till att se fjärrundervisning som central för pedagogisk utveckling och för skolans digitalisering: Sambället digitaliseras allt mer idag. Att använda digitala lösningar $i$ undervisningen är en anpassning till det allt mer datoriserade sambället (R2).

2) Från att sköta sin egen undervisning själv till att se undervisning som en kollegial aktivitet och efterfråga/se behov av ett strategiskt ledarskap, dels för att säkra kvalitet, dels för att möjliggöra utveckling. Man menar att det inte åvilar enskilda pedagoger att ansvara för IT-infrastrukturer etcetera, samtidigt som man ser stor potential till utveckling när ledningen tar ansvar och agerar: Kräver att alla delar i organisationen är delaktiga - buvudman - rektor - lärare - elever - vårdnadshavare (R6).

För denna grupp lärare framstår nu fjärrundervisning som en central del av skolans digitalisering, och de understryker nödvändigheten av att skolledningen går in och utövar ett strategiskt ledarskap.

\section{FJÄRRUNDERVISNING - ET'T STRATEGISKT INSLAG I SKOLANS DIGITALISERING}

Skolans digitaliseringsprocess har pågått i mer är 30 år, i närmare fyra årtionden, och har präglats av statligt finansierade digitaliseringsinitiativ med bas i en obruten teknikoptimism. $\AA$ ena sidan har skolan, via dessa nationella satsningar, givits möjlighet att över tid bygga upp digitala resurser och strukturer (inklusive datorer, surfplattor, lärplattformar och digitala läromedel), samt en viss digital kompetens att planera, genomföra och utvärdera digitala undervisningspraktiker. $\AA$ andra sidan visar forskning och utvärdering av dessa initiativ att pedagogisk och organisatorisk utveckling skett i begränsad omfattning (Hylén, 2013; Jedeskog, 2005; HåkanssonLindqvist, 2015; Skolverket, 2009, 2013, 2016).

För fjärrundervisning utgör digitalisering och tillgång till digitala teknologier, som framgår i denna studie, en viktig förutsättning för att hantera de pedagogiska behov skolan har (se även Millet, 2012), men där tekniken i sig inte utgör någon slags fristående satsning eller en lösning. Istället fungerar strävan om en tillgänglig, högkvalitativ och likvärdig undervisning som ett viktigt mål, som ger digitaliseringen en pedagogisk betydelse, då digital teknik så att säga öppnar upp en väg för att uppnå likvärdighet i skolan oavsett geografisk plats (Pettersson, 2009; Stenman \& Pettersson, 2020). Detta tydliggörs även i denna studie där lärarna, trots inledande oro avseende teknikanvändning, i och med fjärrundervisningen har ett tydligt pedagogiskt objekt med digitalisering och teknikanvändning. Att den digitala tekniken eftersom under läsårets gång integreras i den dagliga undervisningspraktiken i klassrummet kan förstås som att tekniken såväl möjliggör, som bär fram, ett 
alltmer ökande pedagogiskt mervärde för lärarna. Detta innebär, enligt lärarnas egna utsagor, att nya former av undervisning, såväl enskilt som i samarbete med andra, utvecklas, samt att digitala undervisningsformer även utvecklas och tillämpas i den reguljära klassrumsundervisningen (jfr LIIb).

Som framgår i studien förutsätter även fjärrundervisning, för att kunna utvecklas och ta form, ett organisatoriskt utvecklingsarbete på skolan. Som Yu och Chen (2016) och Xiong et al. (2016) också menar behöver pedagoger förutsättningar att utveckla nya arbetssätt och pedagogiska metoder, samt kunskaper att kunna planera, genomföra och utvärdera det nya fjärrundervisningsformatet. Detta ställer, enligt lärarna i studien, krav på att ledning och organisation skapar förutsättningar för digitalisering och pedagogisk utveckling (se även Ottestad, 2013; Pettersson, 2018b; Vanderlinde \& van Braak, 2010). Dels lyfts behovet av ett kollegialt samarbete, dels behovet av ett strategiskt ledarskap för att ge förutsättningar till fortsatt utveckling för att bedriva fjärrundervisning av god kvalitet (jfr LIII). Ovan beskrivna behov och utmaningar ställer även krav på skolledare att utveckla kompetenser för att kunna leda det strategiska och operativa utvecklingsarbetet (jfr Pettersson \& Olofsson, 2019).

Den utveckling som tydliggörs i det empiriska caset utgör ett exempel på hur samspelet mellan ett tydligt skolutvecklingsbehov och digitaliseringens möjligheter drivit på mer skolövergripande, djupgående och långvariga förändringar i den pedagogiska och organisatoriska praktiken (jfr även Häll, Hällgren \& Söderström 2007; Millet, 2012; Pettersson, 2018b; From \& Pettersson, 2018; Xiong et al., 2016). När lärarna fjärrundervisar används digital teknik, vid sidan av de relationer, strukturer och kontextuella förutsättningar som präglar reguljär klassrumsundervisning, med ett pedagogiskt syfte vilket öppnar för ett pedagogiskt mervärde, snarare än som 'business as usual' där digital teknik blir mer av en krydda i vardagliga rutiner (jfr Håkansson-Lindqvist, 2015; Player-Koro 2016). Därmed öppnas också ett utrymme för lärarna för kvalitativt andra typer av pedagogiska erfarenheter och reflektioner relativt den dagliga klassrumspraktiken, ett utrymme som för lärarna i det empiriska caset gav möjlighet till pedagogiskt utvecklingsarbete med hjälp av digital teknik. Fjärrundervisning förefaller sålunda både förutsätta och kunna frambringa såväl digitalisering som ett pedagogiskt och organisatoriskt utvecklingsarbete (jfr LIII), med ett tydligt pedagogiskt objekt (From \& Pettersson, 2018; Pettersson, 2018b; Pettersson \& Olofsson, 2019).

Grunden till fjärrundervisningen som motor i denna utveckling torde stå att finna i det enkla faktum att fjärrundervisningen är sprungen ur skolans pedagogiska och organisatoriska behov, och faktiska förutsättningar och utmaningar. Digitaliseringen leds och drivs därmed utifrån ett pedagogiskt mål och objekt. Fjärrundervisning skulle därmed kunna förstås som ett centralt strategiskt inslag i skolans digitalisering. En rimlig slutsats är därmed att skolans digitalisering är en pedagogisk fråga, inte en teknisk. Med denna 
förståelse av såväl fjärrundervisning som skolans digitalisering blir det således centralt att också förstå de kringliggande strukturer och lokala kontexter som omsluter den pedagogiska praktiken. En förståelse av, och ett sätt att hantera, skolans digitalisering som förefaller betydligt mer produktiv än en teknikoptimistiskt baserad förståelse, som oftast mynnar ut i så kallade blamegames där skolans aktörer pekas ut som orsak till bristande utveckling (Pettersson, 2018a).

Forskningen på området delar nämligen den teknikoptimism som präglat svensk utbildningspolicy under lång tid, och av samma, ovan beskrivna, orsaker (jfr Williamson, 2019). Player-Koros (2012) analys av drygt 600 artiklar inom 'educational technology' visar att cirka $95 \%$ av artiklarna baserades på författarnas tilltro till olika typer av digital teknik, och en förväntad inneboende potential hos tekniken att utveckla den pedagogiska praktiken i skolan: "The tale that framed the articles was almost exclusively optimistic and articulated a strong faith in the capability of educational technology to improve and transform education" (Player-Koro, 2016, s. 100). Ett annat exempel på hur forskning, utbildningspolicy och IT-industri är sammanflätade, med skolan som marknad i sikte, är den årliga Bett-mässan (www.bettshow.com) som marknadsförs som 'The global meeting place for education buyers'.

När det gäller skolans digitalisering är situationen sålunda den att såväl policy som forskning sedan årtionden baserats på en positivt laddad övertygelse om teknikens förväntade möjligheter, och skolan som marknad, snarare är på skolans faktiska behov. När skolan inte utvecklas och förändras som förväntat (trots tillgång till digital teknik) så är logiken att då måste felet ligga hos skolans aktörer, tekniken innehar ju all denna potential, därav de ovan nämnda blame-games (se även Pettersson, 2018a). Varken policy eller forskning tar hänsyn till skolans uppdrag, situation och behov, kontextuella faktorer eller de ramar och strukturer som präglar skolans verksamhet. Inte heller tas hänsyn till att skolans verksamhet är en komplex social praktik, där skolans aktörer är levande människor. Som Fransson, Holmberg, Lindberg och Olofsson (2018) så förtjänstfullt visar så finns det exv. stora skillnader i lärares förhållningssätt till ny teknik, trots att det handlar om lärare i samma ämne, på samma skola och i samma lärarlag. Allt detta talar för att skolans digitalisering bör förstås som en pedagogisk fråga, inte en teknisk eller en fråga om tillgång till teknik. Skolans kärnverksamhet är pedagogisk, med elevers lärande som mål, snarare än teknikanvändning. En utgångspunkt i de pedagogiska behoven skolan har, där digital teknik kan bidra till att realisera pedagogiska objekt, snarare än de möjligheter som den digitala tekniken i sig medför framstår därmed som betydligt mer produktiv för forskning på området. Igen, kort sagt, skolans digitalisering är en pedagogisk fråga, inte en teknisk. 


\section{SLUTSATS OCH FORTSATT FORSKNING}

Med utgångspunkt $\mathrm{i}$ ovanstående resonemang kan skolans digitalisering som begrepp, praktik, studie- och kunskapsobjekt sägas befinna sig i ett skede, åtminstone $\mathrm{i}$ en svensk utbildningskontext, där ingen entydig bild eller definition av skolans digitalisering finns bland forskare, beslutsfattare, profession eller marknadsaktörer, ej heller rörande vad skolans digitalisering ska medföra i termer av teknisk, pedagogisk och organisatorisk utveckling och transformation. Skolans digitalisering, som begrepp betraktat, har många möjliga meningar och innebörder som behöver relateras till skolans lokala kontext och pedagogiska behov. Med andra ord, en utmaning för forskning på området är att beskriva och definiera vad som avses med skolans digitalisering, för att på så vis klargöra vad som studeras och vilka kunskapsanspråk som görs i termer av teknisk, pedagogisk eller organisatorisk utveckling. På så vis kan mer formaliserade diskussioner om skolans digitalisering ta form, med utgångspunkt i respektive skolas pedagogiska och organisatoriska behov - något som i sig kan bidra till en mer nyanserad förståelse för digitaliseringens mening och innebörd inom ramen för svensk skola.

\section{NOTER}

1 From, F. Pettersson och G. Pettersson utvecklade projektidén och studiens övergripande design. Data till studien samlades in av From och G. Pettersson som också genomförde en första databearbetning. Studiens teoretiska inramning utvecklades gemensamt. Analys genomfördes och diskuterades gemensamt av de tre forskarna och ett utkast till artikeltext författades, diskuterades och reviderades gemensamt. Samtliga författare kom överens om val av tidskrift och godkände den slutliga version som skickades in.

\section{REFERENSER}

Agélii Genlott, Annika, \& Grönlund, Åke (2016). Closing the gaps-improving literacy and mathematics by ict-enhanced collaboration. Computers \& Education, 99, 68-80.

Agélii Genlott, Annika, Grönlund, Åke \& Viberg, Olga (2019). Disseminating digital innovation in school - leading second-order educational change. Education and Information Technologies, 24, 3021-3039, https://doi.org/10.1007/s10639-01909908-0 
Andræ Thelin, Annika \& Solstad, Karl Johan (2005). Utbildning i glesbygd-samspel eller konflikt? En kunskapsöversikt. Stockholm: Myndigheten för skolutveckling.

Barbour, Michael K. (2018). Exploring K-12 distance, online, and blended learning worldwide. I R. Ferdig \& K. Kennedy (Eds.), Handbook of research on K-12 online and blended learning (2:a uppl.). Pittsburgh, PA: Entertainment Technology Center Press, Carnegie Mellon University.

Barbour, Michael K. (2019). The landscape of K-12 online learning: Examining the state of the field. I M. G. Moore \& W. C. Diehl (Eds.), Handbook of distance education (Fjärde uppl.) (s. 521-542). New York: Routledge.

Bateson, Gregory (1972). Steps of an Ecology of Mind. Chicago: The University of Chicago Press.

Bock, Annekatrin \& Probst, Larissa (2018). Opening up the classroom: Enabling and interrupting digital media practices in the school. Education in the North, 25(3), 130-138.

Chaib, Christina, Chaib, Mohamed \& Ludvigsson, Ann (2004). Leva med ITiS: Nationell utvärdering av IT $i$ skolan. Jönköping: HLK, Encell/Nationellt kompetenscentrum för livslångt lärande. http://hj.divaportal.org $/ \mathrm{smash} /$ record.jsf?pid=diva $\% 3 \mathrm{~A} 4381 \& \mathrm{ds}$ wid $=-6731$

Creswell, John W. (2003). Research design: qualitative, quantitative, and mixed methods approaches. (2:a uppl.). Thousand Oaks: Sage.

Dahllöf, Urban (1973). Pedagogik. I Leif Lindberg, \& Britt-Marie Berge (Red.), Pedagogik som vetenskap - vetenskap som pedagogik. (s. 189-192). Lund: Studentlitteratur.

de Lange, Thomas (2010). Technology and Pedagogy: Analysing digital practices in media education. Norway: AIT Oslo AS.

Engeström, Yrjö (1987). Learning by expanding: An activity-theoretical approach to developmental research. Helsinki: Orienta-Konsultit.

Fransson, Göran, Holmberg, Jörgen, Lindberg, Ola Jens \& Olofsson, Anders Daniel (2018). Digitalise and capitalise? Teachers' self-understanding in 21stcentury teaching contexts, Oxford Review of Education, 45(1), 102-118. DOI: 10.1080/03054985.2018.1500357

From, Jörgen, \& Pettersson, Gerd (2018). Digitalisering för framtidens skola. Fjärrundervisning - bättre utsikter för fler elever. Stockholm: Ifous.

Graneheim, Ulla \& Lundman, Berit (2004). Qualitative content analysis in nursing research: Concepts, procedures and measures to achieve trustworthiness. Nurse Education Today, 24(2), 105-112. DOI: 10.1016/j.nedt.2003.10.001

Grönlund, Åke (2014). Att förändra skolan med teknik: Bortom "en dator per elev". Örebro Universitet, Örebro. 
Haelermans, Carla (2017). Digital Tools in Education. On Usage, Effects, and the Role of the Teacher. Stockholm: SNS Förlag. https://www.sns.se/aktuellt/digital-tools-ineducation-on-usage-effects-and-the-role-of-the-teacher

Hauge, Trond Eiliv (2014). Uptake and use of technology: bridging design forteaching and learning. Technology, Pedagogy \& Education, 23(3), 311-323. https://doi.org/10.1080/1475939X.2014.942750

Hegerholm, Hallstein (2007). Ekspandering av små skolefelleskap. Nesna: Informatikkseksjonen.

Hylén, Jan (2013). Digitalisering i skolan-en kunskapsöversikt. Ifous rapportserie, 1. https://kfsk.se/larandeocharbetsliv/wpcontent/uploads/sites/8/2015/01/Ifous-Digitalisering-i-skolan-2013-1.pdf

Håkansson-Lindqvist, Marcia (2015). Conditions for technology enhanced learning and educational change: $A$ case study of a 1:1 initiative. (Doctoral dissertation, Department of Education No. 114). Umeå Universitet: Umeå.

Häll, Lars, Hällgren, Camilla, \& Söderström, Tor (2007). Elev- och lärarerfarenheter av fjärrundervisningen $i$ Pajala. Umeå: Umeå universitet, Pedagogiska institutionen.

Jahnke, Isa, Bergström, Peter, Mårell-Olsson, Eva, Häll, Lars, \& Kumar, Swapma (2017). Digital didactical designs as research framework: iPad integration in Nordic schools. Computers \& Education, 113, 1-15. https://doi.org/10.1016/j.compedu.2017.05.006

Jahnke, Isa, \& Kumar, Swapma (2014). Digital didactical designs: Teachers' integration of iPads for learning-centered processes. Journal of Digital Learning in Teacher Education, 30(3), 81-88. https://doi.org/10.1080/21532974.2014.891876

Jedeskog, Gunilla (2005).Ch@nging school.Implementation of ICT in Swedish School, Campaigns and Experiences 1984-2004. Uppsala University: Department of Education.

Jobér, Anna (2015). Social klass i skolan. Det kompensatoriska uppdraget. Stockholm: Natur \& Kultur.

Karlsohn, Thomas (2009). Teknik-retorik-kritik: Om IT-bubblan och datoriseringen av den svenska skolan. Stockholm: Carlsson Bokförlag.

Karlsson, Mia (2004). An ITiS teacher team as a community of practice.

(Doktorsavhandling, Göteborg studies in educational sciences, 216), Göteborg: Acta Universitatis Gothoburgensis.. http://hdl.handle.net/2077/10304

Lundahl, Lisbeth (2016). Equality, inclusion and marketization of Nordic education: Introductory notes. Research in Comparative \& International Education, 11(1), 1-10. https://doi.org/10.1177/1745499916631059

Moon, Jennifer A. (2006). Learning journals - A handbook of reflective practice and professional development (2:a uppl.). London and New York: Routledge Taylor \& Francis Group. 
Millet, James A. (2012). Virtual Learning in K-12 Education: Successful Instructional Practices and School Strategies. Prescott Valley, Arizona: Northcentral University.

Olofsson, Anders D. \& Lindberg, J. Ola (2014). Moving from theory into practice on the informed design of educational technologies. Technology, Pedagogy and Education, 23(3), 285-291. DOI: 10.1080/1475939X.2014.945275

Ottestad, Geir (2013). School leadership for ICT and teachers' use of digital tools. Nordic Journal of Digital Literacy, 8(1-2), 107-125.

https://www.idunn.no/dk/2013/01$\underline{02 / \text { school leadership for ict and teachers use of digital tools }}$

Pettersson, Fanny (2015). Learning to be at a distance: Structural and educational change in digitalizing medical education. Doktorsavhandling, Umeå University: Department of Education.

Pettersson, Fanny (2018a). On the issues of digital competence in educational contexts - a review of literature. Education and Information Technologies, 23(3), 10051021. https://doi.org/10.1007/s10639-017-9649-3

Pettersson, Fanny (2018b). Digitally Competent School Organizations - Developing Supportive Organizational Infrastructures. International Journal of Media, Technology \& Lifelong Learning, 14(2), 132-143.

https://journals.hioa.no/index.php/seminar/article/view/2976

Pettersson, Gerd (2009). Ansökan om att bedriva försö̈ksverksambet gällande distansundervisning för elever i grundskolan och gymnasieskolan inom avgränsade områden (Dnr 505-3529-09). http://www.pedag.umu.se/digitalAssets/207/207612 ansokan gp 2018.pdf

Pettersson, Gerd (2017). Inre kraft och yttre tryck. Perspektiv på specialpedagogisk verksambet i glesbygdsskolor. Doktorsavhandling, Umeå: Umeå Universitet.

Pettersson, Fanny \& Olofsson, Anders D. (2019). Learning to teach in a remote educational context - exploring the organization of teachers' professional development of digital competence. I A. Littlejohn, J. Jaldemark, E. VrielingTeunter, F. Nijland (Red.) Networked Professional Learning: Emerging and equitable discourses for professional development. New York: Springer.

Perrotta, Carlo \& Evans, Michael (2013). Instructional design or school politics? A discussion of 'orchestration' in TEL research. Journal of Computer Assisted Learning, 29(3), 260-269. https://doi.org/10.1111/j.1365-2729.2012.00494.x

Perselli, Ann-Katrin (2014). Frän datasal till en-till-en: En studie av lärares erfarenheter av digitala resurser $i$ undervisningen. Doktorsavhandling 196, Mittuniversitetet.

Härnösand: Mittuniversitetet.

Petko, Dominik, Egger, Nives, Cantieni, Andrea, \& Wespi, Barbara (2015). Digital media adoption in schools: Bottom-up, top-down, complementary or optional? Computers \& Education, 84, 49-61. https://doi.org/10.1016/i.compedu.2014.12.019 
Player-Koro, Catarina (2012). Reproducing Traditional Discourses of Teaching and Learning Mathematics: Studies of Mathematics and ICT in Teaching and Teacher Education. Göteborg, Institutionen för tillämpad informationsteknologi. Göteborg: Göteborgs universitet. http://hdl.handle.net/2077/29043

Player-Koro, Catarina (2013). Hype, hope and ICT in teacher education: a Bernsteinian perspective, Learning, Media and Technology, 38(1), 26-40. DOI: 10.1080/17439884.2011.637503

Player-Koro, Catarina (2016) The contemporary faith in educational technology - a critical perspective, Tidsskrift for Professionsstudier, 12(23), 98-106. DOI: https://doi.org/10.7146/tfp.v12i23.96735

Skolverket (2009). IT-användning och IT-kompetens. Tillgänglig: https:/ / www.skolverket.se/publikationer?id=2192

Skolverket (2013). IT-användning och IT-kompetens i skolan. Tillgänglig: https:/ / www.skolverket.se/publikationer?id=3005

Skolverket (2016). Uppdrag om IT-användning och IT-kompetens i skolan. Tillgänglig: https:/ / www.skolverket.se/publikationer?id=3667

Skolverket (2018). Redovisning av uppdrag om fjärrundervisning. U2015/04701/S 2015$10-01$.

Skolverket (2019). Läroplan för grundskolan samt för förskoleklassen och fritidshemmet (Lgr11). Tillgänglig: https://www.skolverket.se/undervisning/grundskolan/laroplan-och-kursplanerfor-grundskolan

Stenman, Saga \& Pettersson, Fanny (2020). Remote teaching for an inclusive education? An analysis of remote teachers views on remote teaching and their need for pedagogical digital competence. International Journal of Information and Learning Technology. Vol. ahead-of-print No. ahead-of-print. https:/ / doi.org/10.1108/IJILT-10-2019-0096

Sveriges Kommuner och Landsting (2019). Nationell handlingsplan för digitalisering av skolväsendet. Tillgänglig:

https://webbutik.skl.se/shop?funk=visa_artikel\&artnr=7585-773-2

Söderlund, Anders (2000). Det långa mötet - IT och skolan: Om spridning och anammande av IT $i$ den svenska skolan. Doktorsavhandling, Luleå tekniska universitet, 22. Luleå: Luleå tekniska universitet.

Tallvid, Martin (2015), 1:1 i klassrummet: Analyser av en pedagogisk praktik i förändring. Doktorsavhandling, Center for Educational Science and Teacher Research and Research School in Educational Science, 42. Göteborg: Acta Universitatis Gothoburgensis.

Uba, Katrin (2015). Protests Against the School Closure in Sweden: Accepted by Politicians? I Lorenzo Bosi, Marco Giugni, \& Katrin Uba (Red.), The Consequences of Social Movements (s. 159- 184). Cambridge: Cambridge University Press. 
Utbildningsdepartementet (2017). Nationell digitaliseringsstrategi för skolväsendet. Svenska regeringen. Tillgänglig: http://www.regeringen.se/4a9d9a/contentassets/00b3d9118b0144f6bb95302f3e $\underline{08 \mathrm{~d} 11 \mathrm{c} / \text { nationell-digitaliseringsstrategi-for-skolvasendet.pdf }}$

Vanderlinde, Ruben, Aesert, Koen, \& van Braak, Johan (2015). Measuring ICT use and contributing conditions in primary schools. British Journal of Educational Technology, 46(5), 1056-1063. DOI:10.1111/bjet.12282

Vanderlinde, Ruben \& van Braak, Johan (2010). The e-capacity of primary schools: Development of a conceptual model and scale construction from a school improvement perspective. Computers \& Education, 55, 541-553. DOI: 10.1016/j.compedu.2010.02.016

Vetenskapsrådet (2017). God forskningssed. Stockholm: Vetenskapsrådet.

Warschauer, Mark, Zheng, Binbin, Niiya, Melissa, Cotten, Sheila, \& Farkas, George (2014). Balancing the one-to-one equation: Equity and access in three laptop programs. Equity \& Excellence in Education, 47(1), 46-62. https://doi.org/10.1080/10665684.2014.866871

Williamson, Ben (2019). New power networks in educational technology. Learning, Media and Technology, 44(4), 395-398. DOI: 10.1080/17439884.2019.1672724

Xiong, Caiping, Ge, Jun, Wang, Qiyun \& Wang, Xuejun (2016). Design and evaluation of a real-time video conferencing environment for support teaching: an attempt to promote equality of K-12 education in China. Interactive Learning Environments (s. 596-609). https://doi.org/10.1080/10494820.2016.1171786

Yu, Liang \& Chen, Shijian (2016). Synchronous Remote Classroom Connecting K12 Schools in Developed and Undeveloped Areas: A Case Study from China. I Jinbao Zhang, Junfeng Yang, Maiga Chang \& Tingwen Chang (Red.), ICT in Education in Global Context (s. 277-291). Singapore: Springer.

Öjefors-Stark, Anna-Katarina (2019). Fjärrundervisning - perspektiv från skola, region och forskning. Magisteruppsats, Pedagogiska institutionen, Umeå universitet. 